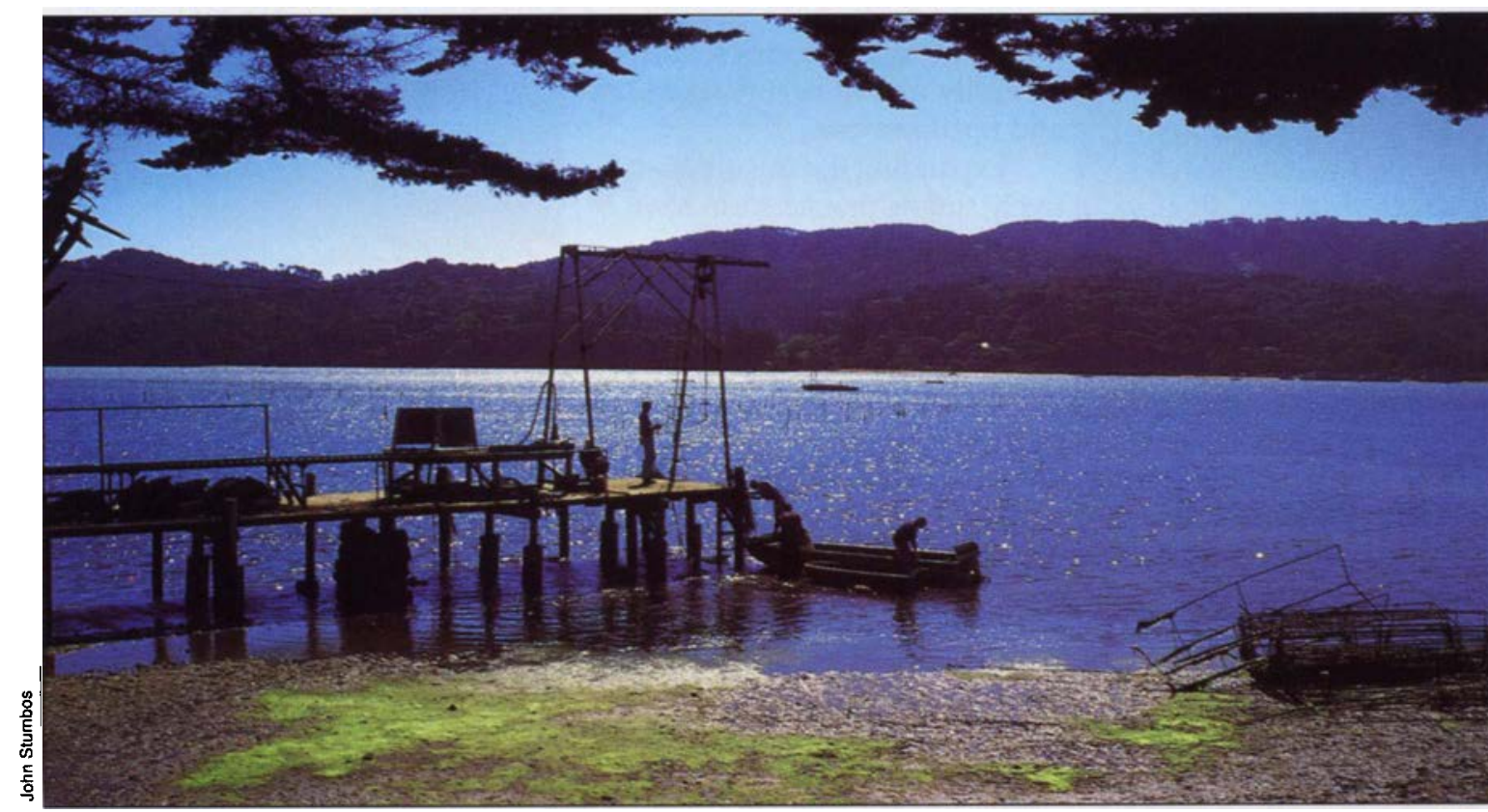

A study about the impact of oyster culture on the health of Tomales Bay in Northern California showed that oyster bags and associated equipment are enhancing marine life in the bay.

One oyster bag typically contains more than 5,000 individual organisms.

\title{
Sea Grant Extension crucial link to coastal resources
}

\section{Few issues illustrate the interdependence of land and sea as vividly as those surrounding Pacific salmon.}

C alifornia's 1,100-mile coastline is a region of spectacle and bounty unsurpassed in the world. No wonder $80 \%$ of the state's population lives in the 20 counties bordering the Pacific Ocean and San Francisco Bay; or that more than 100 million visitors a year come to the state, lured by visions of golden sand and pounding surf.

But the coast harbors more than inspirational scenery. It is a cornerstone of California's economy. In a 1992 study, the California Resources Agency found that seven ocean-dependent industries accounted for 370,000 jobs and contributed more than $\$ 17$ billion to the state's economy, a figure comparable to farm production. Tourism and recreation spending made up the largest economic component, followed by seaport activity; offshore oil, gas, and mineral production; commercial fishing; mariculture; and kelp harvesting (see box, opposite).

Working with these marine industries is a small team of UC professionals - two marine specialists and seven county-based advisors who make up the California Sea Grant Extension Program, which is celebrating its 25th year. Uniquely positioned within both Cooperative Extension and the California Sea Grant College System, this team has access to UC's land-grant research and extension service, to marine-science programs at campuses and to coastal research facilities statewide (see page 16).
"We develop practical solutions to marine and coastal resource problems throughout the state," says Chris Dewees, the program's coordinator and UC Davis marine fisheries specialist. "From wetlands education to waterfront development, we have become involved in issues touching many aspects of coastal life." In other efforts, the Sea Grant Extension team has helped restore habitat for salmon and steelhead, advanced coastal aquaculture, schooled seafood handlers in new safety practices, provided children with hands-on understanding of water quality issues, applied high technology to fisheries management and showed coastal boat owners how to keep pollutants out of harbors.

"We're all bound together," Dewees notes. "Coastal environments are affected by activities that occur far inland through changes in the delivery of water, as well as the addition of sediments, nutrients and contaminants. And inland dwellers rely on the sea for food and recreation."

\section{The link between land and sea}

Few issues illustrate the interdependence of land and sea as vividly as those surrounding $\mathrm{Pa}$ cific salmon. How humans choose to manage natural resources will mean the difference between survival and extinction for many runs of migrating Chinook and coho salmon, as well as steelhead and cutthroat trout, in coastal and in- 


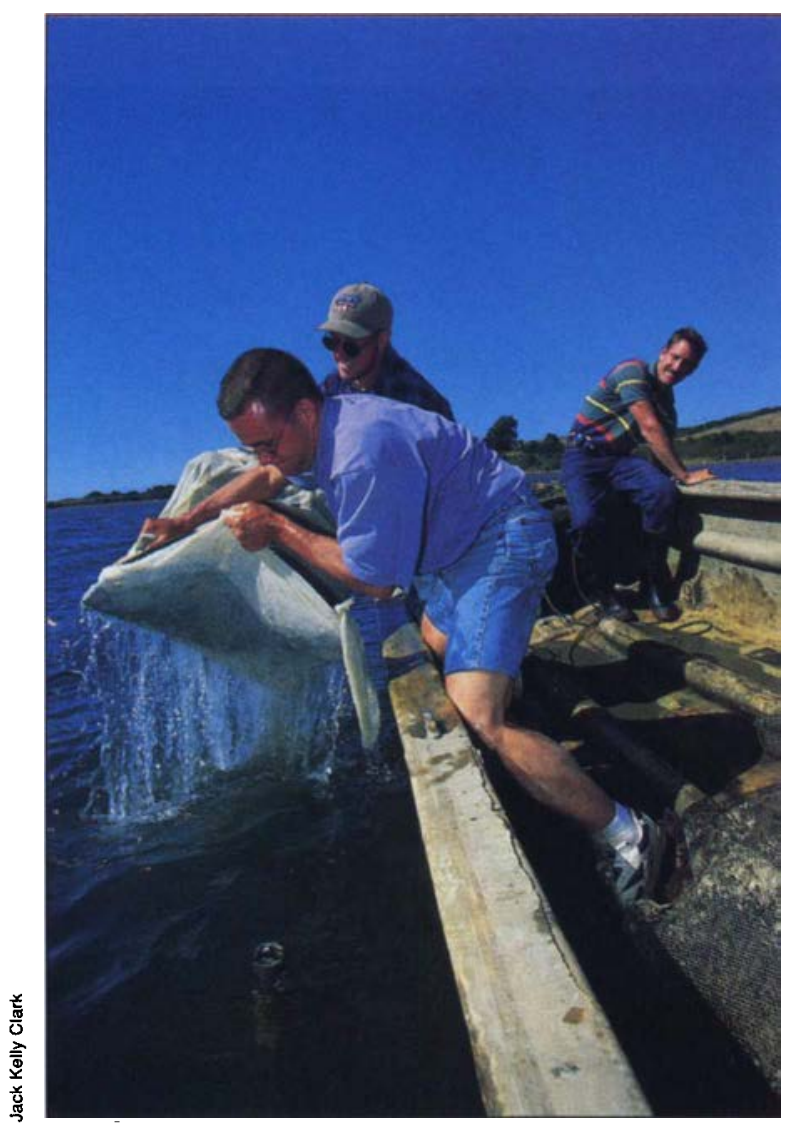

land rivers and streams alike. Already, spawning habitat has been drastically reduced. In the Central Valley, more than 1 million Chinook salmon once had access to several thousand miles of rivers and streams, according to UC Davis fisheries professor Peter Moyle. Today a small fraction of that number have access to fewer than 300 miles of suitable spawning habitat. Although fish hatcheries have mitigated some of the impacts on these historic runs, it is wild fish and, therefore, wild habitat that are crucial to ensure a genetically resilient population that can survive changes in the environment.

Two of the best remaining wild habitats for spring runs of Chinook salmon are Mill Creek and Deer Creek, which tumble down the west slope of the Sierra Nevada in the upper Sacramento Valley. The creeks are undammed and relatively pristine. Much of the surrounding countryside is private ranchland.

To help ensure the long-term survival of the Chinook salmon in these creeks, Sea Grant specialist Christopher Dewees worked with Nat Bingham of the Pacific Coast Federation of Fishermen's Associations and Sea Grant staff research associate Leon Davies to organize what is now known as the Spring-run Chinook Salmon Workgroup. With financial support from governmental and nonprofit sources, the group has been meeting monthly since 1993 to identify problems and develop solutions. These meetings have led to a broad range of habitat protection and restoration measures and the formation of watershed conservancies.

"The workgroup has brought together a wide range of stakeholders committed to a common goal," Dewees notes. "These people have worked together at the local level to protect and improve salmon habitat. They have accomplished the sort of things that would have been required under the Endangered Species Act had their salmon runs been listed as threatened or endangered."

Dewees, a marine fisheries specialist, also examines alternative methods of managing limited fisheries resources. He has conducted research on "individual transferable quotas" with colleagues in New Zealand and Canada and says the concept - while not a panacea - holds promise for some beleaguered fisheries (see page 27).

\section{Restoring a vanquished resource}

In the far northwestern corner of the state is a project to monitor especially large strains of Chinook salmon and steelhead trout. These magnificent ocean-going fish - Chinook as large as 70 pounds - fight their way past finned, feathered and two-legged predators to the tributaries of the Smith River to spawn and complete their anadromous life cycle.

For 17 years, Jim Waldvogel, Sea Grant's marine advisor in Del Norte County, has been monitoring the migration of Smith River Chinook in one of the river's tributaries, Mill Creek (distinct from Mill Creek in the Sacramento Valley). Initiated as a result of public hearings that led to "wild and scenic" status for the Smith River, the Mill Creek study is the longest-running spawning study of Chinook salmon in California (see page 28). It has provided information on the health of the watershed at critical junctures. For instance, it recently persuaded California Department of Transportation officials to abandon plans to construct an alternate route for Highway 101 through the Mill Creek watershed.

While the Smith

River system is in comparatively good

\section{Ocean-dependent industries generate $\$ 17.3$ billion}

Ocean-dependent industries in California support 370,000 jobs and contribute $\$ 17.3$ billion to the state's economy, according to a 1992 study reported in California's Ocean Resources: An Agenda for the Future.

\begin{tabular}{|c|c|c|}
\hline & $\$$ billions & $\%$ \\
\hline Tourism & 9.9 & 57 \\
\hline $\begin{array}{l}\text { Water transportation } \\
\text { (freight and passengers) }\end{array}$ & 3.4 & 20 \\
\hline Ship building & 2.6 & 15 \\
\hline $\begin{array}{l}\text { Offshore oil, gas and } \\
\text { mineral production }\end{array}$ & 0.862 & 5 \\
\hline $\begin{array}{l}\text { Commercial fishing, mariculture } \\
\text { and kelp harvesting }\end{array}$ & $\underline{0.554}$ & $\underline{3}$ \\
\hline Total & $\$ 17.316$ & $100 \%$ \\
\hline
\end{tabular}

Source: California Research Bureau, California State Library 


\section{The first 25 years...}

shape, the same cannot be said of many rivers on the North Coast, which have suffered from past timber practices, sedimentation due to erosion, and water diversions. The resulting loss of spawning habitat, along with similar declines in Central Valley streams, has taken a toll on a once thriving salmon industry. Resource management agencies have been forced to implement seasonal closures and other restrictions that have left commercial fishers with few alternatives but to fish for other species, travel hundreds of miles from home for weeks or months at a time or find another vocation.

Shortly after his arrival in Crescent City in 1979, Waldvogel and other marine advisors recognized the need to get technical information to volunteer watershed groups. In 1983 they organized the first Salmon and Steelhead Restoration Conference, which drew more than 150 people. Volunteers learned about subjects such as salmonid genetics, capturing broodstock, building weirs and providing spawning gravel. Now under the auspices of the California Salmon and Steelhead Restoration Federation, the conference continues as a major annual event. Similar conferences have since sprung up throughout the Pacific Northwest and Canada.

"Working toward the enhancement of fishery resources brings a community together," Waldvogel observed in a special publication commemorating the first 20 years of the Sea Grant program. "We suddenly see cooperation among people who have more often than not been at odds with each other - anglers, loggers, ranchers, commercial fishermen, land developers and public agencies."

Waldvogel expects to continue his role as a technical advisor to resource agencies and local government groups on issues concerning salmonid species. Of imminent concern is the listing of coho salmon and steelhead stocks for protection under the Endangered Species Act. "There could be major impacts to land use practices," Waldvogel says. "Virtually anything that could impact the water in which these fish live could be affected."

\section{Fostering fishery resources}

To the surprise of many people, the most valuable commercial fishery along the California coast is not salmon, tuna or other finfish. It's "uni" — the golden-yellow roe of sea urchins - a Japanese delicacy worth $\$ 25$ million a year to California. More than $90 \%$ of the product is exported.

\section{California Sea Grant: a model for addressing coastal resource issues}

As Cooperative Extension's academic professionals devoted to coastal resources, the Sea Grant marine advisors and specialists perform a unique function within UC's vast realm of marine sciences. The team is also the formal public-service branch of the California Sea Grant College System, headquartered at UC San Diego's Scripps Institution of Oceanography.

The Sea Grant program began on a national level in 1966 with the enactment by Congress of the Pell-Rogers Sea Grant College and Program Act. The heart of its mission is long-term economic development, stewardship and responsible use of marine, coastal and Great Lakes' resources. The name "Sea Grant" was chosen to emphasize the program's similarities to the landgrant college program in its orientation to national economic development through the involvement of higher education. Like its landgrant cousins, Sea Grant seeks to promote close relations between academic, governmental and industrial institutions through research, education and extension activities.

Assigned to the National Oceanic and Atmospheric Administration (NOAA) in the U.S. Department of Commerce, Sea Grant has grown to a national network involving more than 300 universities and affiliated institutions in 29 states and Puerto Rico.

In California, Sea Grant began modestly in 1968 with an award to Scripps for the development of an interdepartmental, graduate-level curriculum in applied ocean science. Other projects quickly took root at neighboring San $\mathrm{Di}$ ego State University, UC Santa Barbara and other California universities. In 1971, at the request of UC President Hitch, UC formally applied to the NOAA for "institutional status"; 2 years later, the university was designated a Sea Grant College "for sustained excellence."

Early in its development, the administrators of California Sea Grant made several important decisions that would influence its future devel- 
opment. One was to house the marine advisory program within Cooperative Extension rather than to create a whole new administrative structure. A second critical decision was that Sea Grant would be open to any state or private university to encourage participation by the broadest possible range of talent, interest and facilities. Today, Sea Grant-funded projects are also found at Stanford, Humboldt State and the California Institute of Technology. In addition to the California Sea Grant College System, a small separate Sea Grant program, with an emphasis on "urban ocean" issues, exists at the University of Southern California.

With an annual budget averaging $\$ 4.5$ million, California's Sea Grant program is the largest in the nation. A robust competitive-grants program funds research into a broad range of subjects related to aquaculture, fisheries, marine biotechnology, ocean engineering and other coastal resource subjects. Recently completed projects assessed the seismic risk posed by an offshore fault zone; looked into the use of hormones to stimulate abalone growth; tested edible films designed to preserve the quality of frozen fish; studied the oceanic processes affecting movement of rockfishes; investigated the use of quotas in fisheries management; and studied the invasion of an exotic crab in California estuaries.

Sea Grant also has an ambitious program in support of graduate student education in marine-related studies and annual fellowship programs designed to provide opportunities for those interested in public policy.

Sea Grant research has had far-reaching consequences for the use of California's coastal resources. It laid the foundation for and continues to foster the state's marine aquaculture industry, including the culture of abalone, scallops and other mollusks. It has yielded new compounds from the sea with applications in medicine and other industries. It has led to a deeper understanding of the biological and geological pro-

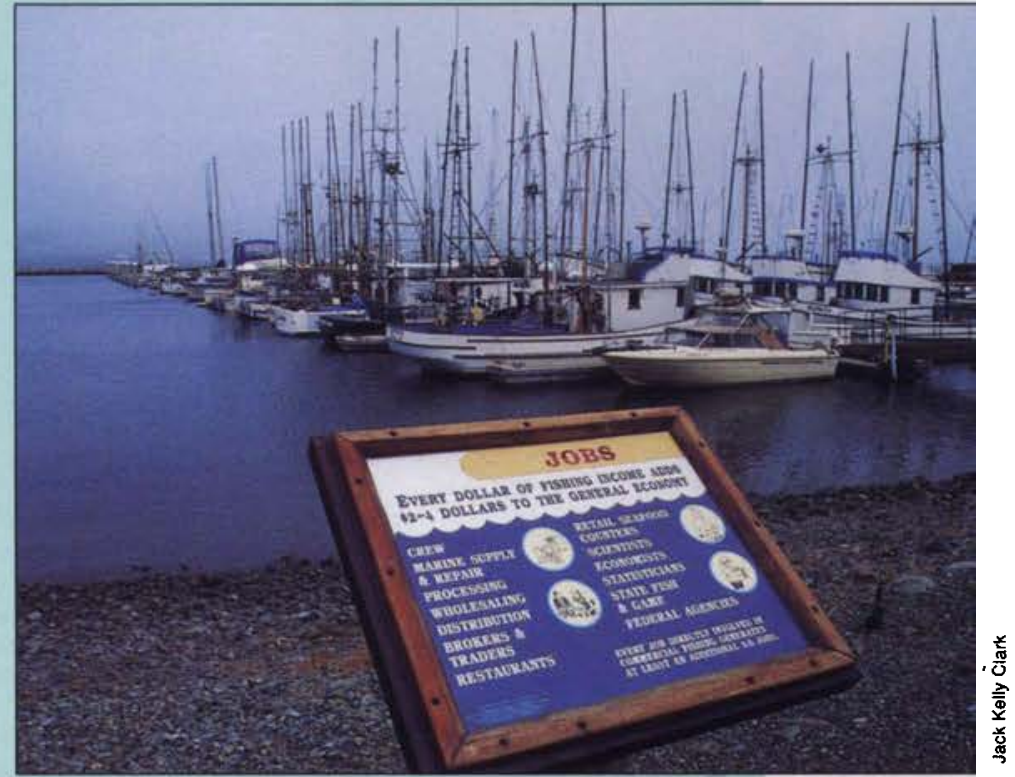

The information generated by the nation's largest Sea Grant program has had far-reaching consequences for the use of California's coastal resources: the foundation of marine aquaculture, new medicines from the sea, improved safety of oil and gas technology and the improved productivity and sustainability of California's commercial fishing industry.

cesses that drive coastal ecosystems. It has spurred improvements in the safety of offshore oil and gas structures and other technology for working in the oceans. And it has contributed to the wise use of coastal resources by state and local planners.

"The Sea Grant program today provides a powerful state and national capability in marine research, extension and education," notes California Sea Grant's director, James J. Sullivan. "We were extremely pleased to see the university honored recently by the state Legislature for California Sea Grant's leadership in addressing coastal and marine issues."

"California Sea Grant has become a model for fostering communication and collaboration among the educational, governmental and private sectors," wrote William R. Frazer, UC's senior vice president for academic affairs at the time of the program's recertification in 1989. "In this regard, Sea Grant's marine advisors and specialists, housed within the University of California Cooperative Extension, merit special mention. They have played a particularly important role in facilitating the flow of information between the broader marine community and university-based researchers." - J.S. 


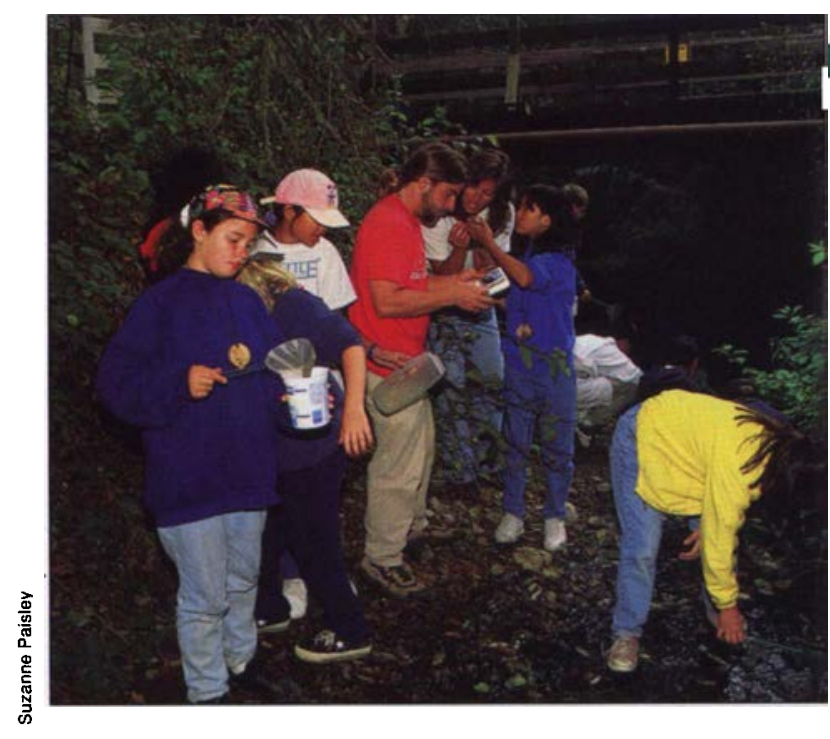

continued from p. 16

Uni from

California's sea urchins is among the most highly regarded in the world for color, texture and taste. Urchins are harvested by nearshore dive fishers who search the ocean floor to harvest a top quality catch. A kilogram of grade A uni, often packed in hand-

Marine advisor Jodi Cassell and Colin Hubbard, environmental education specialist at UC's Elkus Ranch, explore the "outdoor classroom" of Purisima Creek with San Francisco Bay Area schoolchildren.

\section{"Purisima Creek is} a microcosm... an ideal place to get students to see the connection between water use and environmental concerns." crafted wooden boxes, may fetch as much as $\$ 100$, while grade $B$ may be worth less than half that amount. The significant difference in price, which affects diver and processor alike, is a reflection of subtle differences: The highest quality uni has a bright saffron color and a firm, dry surface appearance.

Could sea urchin roe be raised using holding tanks - much the same way cattle are fattened in a feedlot - to bring the industry a better return and more consistent supply? That's a question under study by Susan McBride, Sea Grant marine advisor for Humboldt and Mendocino counties. At the Humboldt State University Marine Laboratory in Trinidad, McBride has examined how urchins respond to various prepared and algal diets under different environmental conditions (see page 30 ).

Like other marine advisors, McBride's job also involves working with a wide array of people and groups. During discussions for redevelopment of the Eureka waterfront, McBride served as a liaison between fishers and local planning groups to ensures that the concerns of the commercial fishers were understood and addressed.

The north end of the Eureka waterfront is anchored by stately Victorian houses, art galleries, crafts shops, upscale restaurants and other economic improvements that cater to locals and tourists alike. The waterfront's southern end, on the other hand, seems to have been cast adrift from this economic revival. City planners were considering rezoning the south end of the waterfront from industrial to commercial, but local commercial fishers were concerned about getting pushed aside by tourism.

"The city did not rezone but did move the fishers' work and storage area north, to a 1-acre parcel adjacent to a commercial area frequented by tourists. The idea of a working waterfront as a way to mix both industry and tourism is very popular here," she said. Construction of a new fishing dock adjacent to the parcel is scheduled to begin in 1997.

\section{The outdoor classroom}

In 1975, the Elkus family donated a 400-acre ranch south of San Francisco to UC for outdoor educational programs for urban, disabled and inner city youth. Each year, hundreds of Bay Area youngsters - some of them in preschool - learn where their food comes from by tending a vegetable garden or gathering eggs from a henhouse. Others learn how water cycles through the environment and why it is important to prevent water pollution; still others may examine marine resources in nearby tidepools, tidal marshes and coastal creeks.

Jodi Cassell, the San Francisco-based marine advisor, confers with the staff at the Elkus Ranch on educational curricula for their programs. One approach encourages students to assess stream health by examining water quality. "The thing that makes Elkus unique is that everybody in Purisima Creek canyon - farms, ranches and homes - gets water from the creek," Cassell says. "In that sense, Purisima Creek is a microcosm for California's water quality and water quantity issues, so it's an ideal place to get students to see the connection between water use and environmental concerns."

Cassell is also holding a marine sciences boot camp for volunteer 4-H leaders this fall. "Trainthe-trainer" programs are on the increase, as extension personnel attempt to get critical information from UC to a variety of audiences. In the coastal community of Half Moon Bay, Cassell is developing a similar program to train schoolteachers about watershed restoration projects.

Schoolchildren aren't the only ones Cassell is talking to about watersheds and marine resources. She and colleagues at the San Mateo County Resource Conservation District received a federal grant to educate San Mateo County ranchers and landowners about coho salmon and steelhead trout habitat needs. With the recent listing of coho salmon as a threatened species in many areas of California, Cassell says, coastal landowners may be anxious to learn what potential restrictions await them and how they might adjust management practices to help save this important fish from extinction.

As an undergraduate at Harvard University, Cassell had originally planned a career in medicine. Given her early interests, it is no surprise that she has turned her attention to the human continued on $p .21$ 
passing H.R. 4283, the National Invasive Species Act, which seeks to prevent the introduction and spread of nonindigenous species by ballast water operations in U.S. waters.

But what, specifically, can be done to lessen the impact of these alien invaders? To address this question, we organized a California Sea Grant Program Development Workshop this past October, for scientists and government policy makers who are concerned about the problem. Our objective was to provide education about research efforts that are under way and to identify future research, management and education needs related to aquatic nuisance species. The results will be published by California Sea Grant later this year (California Sea Grant, in press).

By forming linkages between academic and agency scientists and managers, and by providing broad outreach activities aimed at educating the general public, California Sea Grant's extension advisors can make an important contribution to addressing this issue.

J.L. Cassell is UC Cooperative Extension Sea Grant Marine Advisor for the San Francisco Bay counties.

\section{References}

Anderson LWJ, 1996. Eradicating California's hydrilla Aquatic Nuisance Species Digest 1(3). Navarre (MN): Freshwater Foundation. p. 25-33.

California Sea Grant. Forthcoming. Proceedings from the October 1996 workshop on Nonindigenous Species: Current status and research needs. Millbrae, CA. 30 p.

Cohen AN, Carlton JT. 1995. Nonindigenous aquatic species in a United States estuary: A case study of the biological invasions of the San Francisco Bay and Delta. Biological study. Springfield (VA): U.S. Department of Commerce, NTIS. $285 p$

Great Lakes Panel on Aquatic Nuisance Species (Great Lakes Commission). 1996. ANS Update 2(1):5 Janik J. 1996a. Personal communication. State of California, Department of Water Resources, Sacramento, CA.

Janik J. 1996b. Presentation at the October 18-19, 1996, California Sea Grant Nonindigenous Species Workshop, Millbrae, CA.

Snyder FL et al. 1994. Zebra Mussels in North America: The Invasion and Its Implications. Columbus $(\mathrm{OH})$ : Ohio Sea Grant College Program. 4 p.

U.S. Army Corps of Engineers. 1994. Zebra musse research: Technical notes. Compiled by Zebra Mussel Research Program. Vicksburg (MI): Waterways Experiment Station. $98 \mathrm{p}$.

Zook WJ. 1995. An Assessment of the Potential for Introduction, Local Adaptation, and Environmental Impact of the Zebra Mussel in Washington State. State of Washington, Department of Fish and Wildlife, Olympia (WA). $18 \mathrm{p}$. continued from $p .18$

health aspects of fishing in the San Francisco Bay. Bay Area health officials are concerned that potentially dangerous levels of PCBs, mercury and other pollutants are making their way into the fish-heavy diets of recent Southeast Asian immigrants. In collaboration with Cooperative Extension nutritionists, Cassell is developing materials for the region's public health care professionals to educate this at-risk group. The plan is to educate them through cooking demonstrations

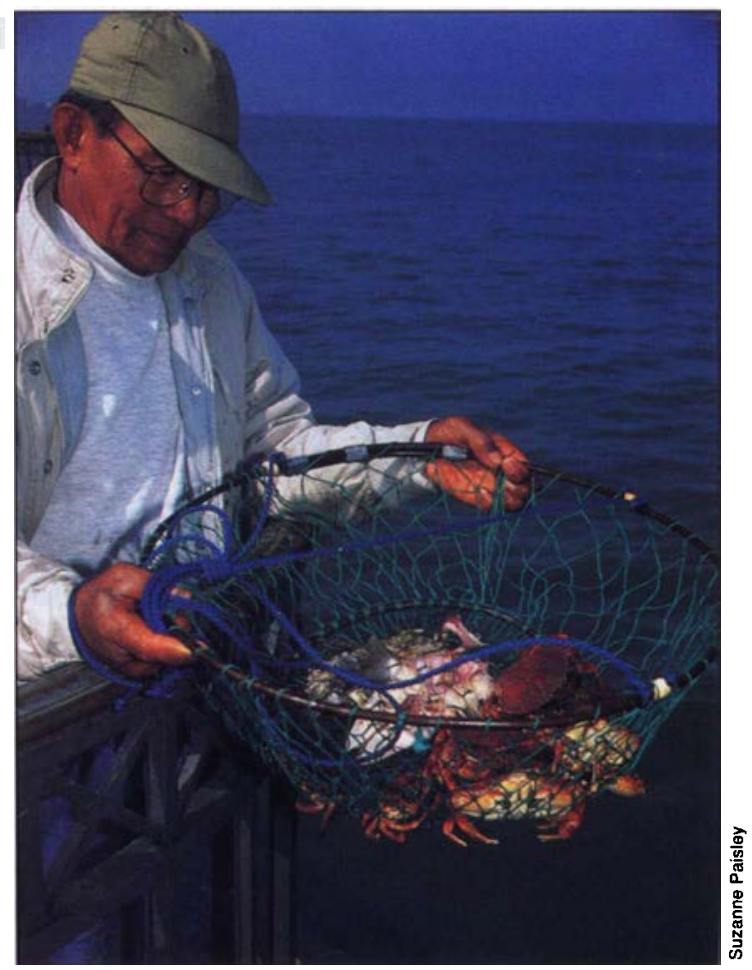

and other means about preparing fish safely and avoiding unsafe parts altogether.

Another facet of Cassell's work involves educating the shipping industry and the general public about the threats posed by exotic species, particularly fast-spreading zebra mussels, which not only threaten to displace native species but can clog public water systems (see page 19).

\section{Ensuring seafood safety}

One of the biggest challenges in the early days of the Sea Grant Extension Program was just getting noticed. "When we first started, Chris Dewees and I did a lot of consumer education - how to buy fish, what species were available - to get the Sea Grant name out there," said Bob Price, the extension specialist in seafood safety and technology.

Seafood processors were particularly skeptical. "They had no contact with extension, no clue what we were about," Price said. "I was even asked to leave a few places. I had to convince them that I wasn't there to steal trade secrets or to regulate them."

In the 25 years since, Price has developed a variety of projects helping seafood processors tap into new technologies; showing retailers how to tighten sanitation practices; and educating consumers in safety and quality (see page 50 ). His efforts have earned him a national reputation for seafood safety education and accolades from the Institute of Food Technologists and the California Fisheries and Seafood Institute.

Seafood consumption has grown dramatically in recent years, and with it a concern about the
The seafood-heavy diets of Southeast Asian immigrants make them particularly at risk for consuming potentially dangerous levels of PCBs, mercury and other pollutants. 


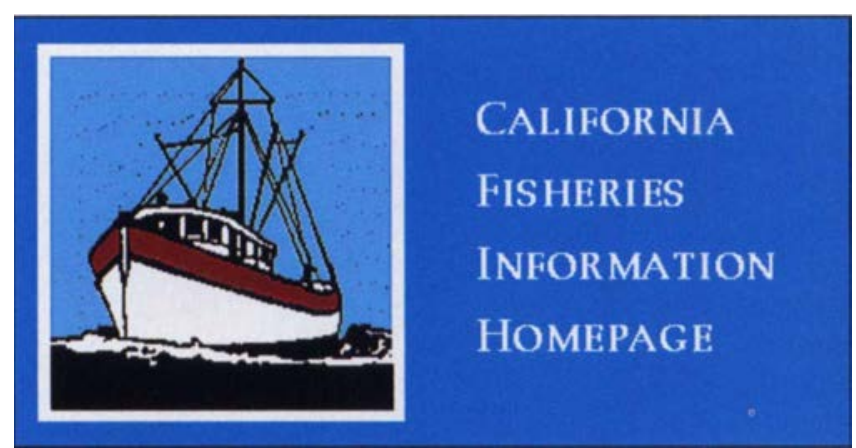

The Callfornia Fisherles Home Page links more than 50 Internet sites on weather, seafood research, pending legislation and coastal and ocean management topics. (http://www.calpoly. edu/ bio/jstannar/).

According to the United Nations, demand for food fish will exceed supply by 30 million tons in the year 2000. world, Price says. wholesomeness of seafood Price has been educating regulatory agencies about the Hazard Analysis and Critical Control Point (HACCP) system, which seeks to identify and eliminate potential risks to food safety. HACCP (pronounced "Hassip") was developed by NASA to prevent astronauts from getting food poisoning in space. Recent federal legislation requires seafood processors and retailers to implement a HACCP plan by Dec. 18, 1997.

Price and associate Pamela Tom are also stewards of an Internet-based seafood network discussing seafood safety issues. A seafood HACCP listserv can be accessed through listproc@ucdavis.edu, and the Web address for the Seafood Network Information Center (NIC) is http://www-seafood.ucdavis.edu/. In just over a year, both of these resources have proven to be an effective means of networking with key industry and government people throughout the

New techniques for ensuring food safety tops the list of areas ripe for research developments. "We need rapid analytical procedures that could be adapted at the plant level to monitor for bacterial contaminants and marine toxins," Price says. Currently no such technology exists.

Visitors to the Seafood NIC home page find updated seafood regulations, meeting announcements and compelling graphics, including a virtual aquarium of fish images. In addition, the site is linked to the Food and Drug Administration's encyclopedia of electrophoretic scans - essentially DNA thumbprints - to help commercial laboratories ensure correct identification of fish. These labs are consulted by state regulators, fish retailers or fish processors who wish to confirm the identity of a filleted fish.

"When you have a filet in your hand it's hard to tell what it is," Price says. "This is a big problem all over the world. You have to trust who you're buying the fish from. There are a lot of inexpensive fish available in tremendous quantities, such as Alaskan pollock, that can easily and misleadingly be marketed as a more valuable product."

\section{Farming the sea}

California's aquaculture production has increased steadily for more than a decade. Marine organisms under cultivation include abalone, scallops, mussels, several types of oysters and sturgeon. Commercial abalone production has risen dramatically - up from 2 million pounds in 1992 to 3 million pounds in 1993, an increase from 4.7 to $6.4 \%$ of the state's total aquaculture production. Global trends are also driving aquaculture development. According to the United Nations, demand for food fish will exceed supply by 30 million tons in the year 2000 .

Two factors seriously limit abalone aquaculture: the mollusk's slow rate of growth and the limited, unpredictable supply of its native food, kelp. Both limitations make business planning difficult and sometimes precarious. Cultured abalone typically require 4 years to reach 3 - to 4-inch market size, but that period can be even longer if kelp is in short supply. For instance, kelp dies back during El Niño events. In addition, there are increasing regulatory controls on kelp harvesting. These factors make the development of cost-effective artificial feeds essential to the future of this industry.

Paul Olin, marine advisor for Marin and Sonoma counties, is testing several experimental abalone diets in collaboration with Bodega Farms, an aquaculture operation north of San Francisco on a windswept bluff overlooking the Pacific Ocean (see page 7). At present, the company provides international consulting services on abalone culture and supplies juvenile abalone "seed" to be shipped off to abalone farms worldwide.

"Three commercially available abalone diets have all supported comparable growth rates," Olin says, "although they vary in price from $\$ 1.70$ to $\$ 5$ a pound." Since aquaculture feed generally averages about $40 \%$ of production cost, this represents a significant area for savings.

Down the road from Bodega Farms, the marine advisor is also conducting research on oysters cultured in the shallow waters of Tomales Bay (see page 54). Oysters are typically grown in polyethylene mesh bags that are placed on the bottom of the bay, suspended in racks or floated on the surface. "With increasing attention to coastal resources," he observes, "there has been some concern about the effect oyster culture may have on other components of the Tomales Bay ecosystem."

Olin and two student interns surveyed the bay's habitat. "Our research showed that more than 60 species use this gear for habitat," Olin 
says. "A single oyster bag contained more than 5,000 organisms, including fish, crustaceans and thousands of aquatic invertebrates - amphipods, isopods, bryozoans and polychaetes." Although some organisms are removed with harvest, others swim away to alternative habitats.

\section{Fine-tuning fisheries management}

Twenty years ago marine advisors focused much of their effort on improving fishing efficiency, helping commercial fishers boost their catch or improve the quality of the end product. Today, fishing vessels are routinely equipped with sonar, echosounders and global positioning systems with plotters. The commercial fishing industry has become very effective at catching fish - in some cases, too effective. "We're now looking at improved methods of assessing fish populations to help the fishing industry and government agencies do a better job of managing fishery resources," says Rick Starr, marine advisor for Monterey and Santa Cruz counties.

The eastern Pacific is home to more than 60 species of rockfishes, Starr says, and at least 50 of them can be found in Monterey Bay. Fishing pressure on rockfishes has intensified greatly in recent years, so Starr and fellow marine scientists in the Monterey Bay area are developing advanced computer-generated images of the ocean floor to study species-habitat associations and provide fisheries managers with the information they need to ensure the long-term sustainability of rockfishes and other species.

In studies of Monterey Bay and the Big Creek Ecological Reserve off Big Sur, Starr and colleagues are using a small research submarine, sidescan sonar and sonic tags implanted in fish to monitor rockfish distributions and movements. The data are entered into a geographical information system (GIS) at the Center for Habitat Studies at the Moss Landing Marine Laboratory. They are used to create images of fish habitats and movements, helping scientists determine how well the reserve sustains fish populations and the local fishery (see page 41).

The designation of Monterey Bay as a National Marine Sanctuary in 1992 required the development of a comprehensive water quality protection plan for the area's watersheds, which include the Salinas Valley, one of the most productive agricultural regions in the world. Starr helped bring resource managers, industry, and nongovernmental conservation organizations together to develop a water quality protection plan for the sanctuary. The group recommended best management practices to limit nonpoint- source pollution from urban areas, harbors, marinas and farms. Eventually, Starr says, remote sensing tools such as satellite images will be combined with monitoring information to help managers identify and assess water pollution problems.

The waters off the coast of Santa Barbara are part of the Channel Islands National Marine Sanctuary, one of only 12 such areas in the United States that have gained this special protected status because of their significant natural and cultural resources. These sanctuaries, as well as other types of reserves and preserves, are collectively known as "marine protected areas" (MPAs).

In California there are 104 such MPAs under the jurisdiction of institutions ranging from UC to the United Nations. UC operates 10 natural land and water reserves within the coastal zone for teaching and research.

"California's marine protected areas have been created on a case-by-case basis," notes Deborah McArdle, marine advisor for Santa Barbara and Ventura counties. "As a result, information about this wide array of ecosystems has been scattered and inconsistent. Fishers, resource managers and scientists have all expressed confusion over the complexity of these designations."

\section{Linked to the Internet}

To address this problem, McArdle has compiled a computer database of information on the nature of California's protected areas, their locations, and regulations affecting their use by fishers and recreational divers (see page 33). The database includes digitized maps of each area, the result of a collaboration with the Remote Sensing Research Unit at UC Santa Barbara. In addition, she recently published California Marine Protected Areas, a book that shows where MPAs are located in California, the agencies responsible for their management, different MPA classifications and related information.

McArdle routinely gives presentations on these protected areas to fishing groups, city councils and others. She has also developed and manages an Internet-based discussion group called the California Marine Protected Areas Network (CMPAN). CMPAN can by accessed by sending "subscribe cmpan" in the text of an e-mail message to listproc@ucdavis.edu.

McArdle has also compiled fisheries information at one location - the California Fisheries HomePage, which links more than 50 Internet sites on weather, seafood research, legislation and fisheries management. The home page

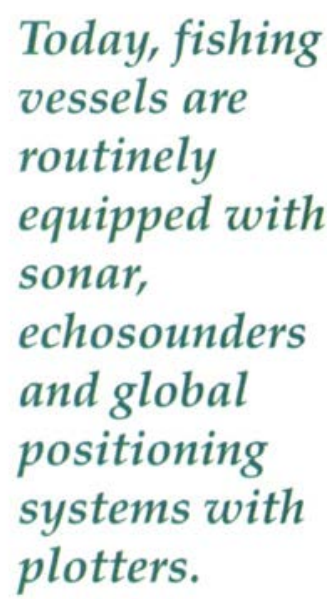


“We explained to the farmers that they had an opportunity to 'get a seat at the table' by being part of the process... They liked that." serves resource managers and researchers, as well as commercial and sport anglers (http:/l www.calpoly.edu/ bio/jstannar/).

\section{Carrying out public policy}

Nonpoint-source (NPS) pollution - the waste that flows from myriad human activities rather than a single, identifiable source - has become a matter of increasing concern among legislators and environmental agencies. In 1990, the federal Coastal Zone Act Reauthorization Amendments became law and with them a mandate to manage coastal nonpoint-source pollution. NPS pollution includes grease and oil washed off city streets into storm drains, as well as sediment from erosion, heavy metals from marinas and fertilizers and pesticides from farms. According to the U.S. Environmental Protection Agency, agriculture is the leading contributor to this type of pollution.

Leigh T. Johnson, marine advisor in San Diego County, serves an area where extensive urbanization looms over 23 coastal wetland areas and coexists with a $\$ 1$ billion agricultural economy. In 1991, she and Valerie J. Mellano, environmental issues advisor for San Diego County Cooperative Extension, obtained a USDA grant to help agricultural producers, environmental groups and government agencies reduce agricultural impacts on coastal water quality.

"We explained to the farmers that they had an opportunity to 'get a seat at the table' by being part of the process," Johnson recalls. "That was new to them. They liked that."

The advisors interviewed people representing the three groups to identify issues, concerns and needs for technical information. At two public forums, the representatives began exploring possible solutions. Some were surprised to learn that the area's farmers were already using "best management practices," such as drip irrigation to reduce runoff and contamination from fertilizers and pesticides.

The process resulted in specific recommendations to address coastal water quality problems. The effectiveness of the project prompted Farm Bureaus in three neighboring counties to form a joint NPS pollution management committee. Johnson's office also recently produced San $\mathrm{Di}$ ego County Wetlands, which includes recommended practices to help growers minimize NPS pollution from their farms. Mellano used it in her follow-up education program on agricultural best management practices.

Johnson's work with groups having conflicting viewpoints follows the tradition of marine continued on p. 26

\section{Diverse groups team up to fight pollution}

\author{
Leigh Taylor Johnson
}

Legislation aimed at water pollution abatement may create strange, and sometimes seemingly incompatible, bedfellows. But in at least one instance, legislation on nonpoint-source pollution provided an opportunity for government, environmentalists and members of the agricultural and recreational boating industries to make a clean start at overcoming what had previously been mutually frustrating attempts at communication.

The legislation in question was the Nonpoint Source Pollution Program, passed by Congress as an amendment to the Coastal Zone Act in 1990. Two novel aspects of the program were that it required public involvement in developing and implementing pollution "management measures" and that the management measures be economically achievable.

In response to this legislation, the San Diego County Cooperative Extension initiated a joint public-issues program focused on the effects of agriculture on coastal nonpoint-source pollution. We worked with agricultural producers, government agencies and environmentalists to educate the groups to one another's perspectives. The project proved so successful that we decided to use it as a model for working with the recreational boating industry.

Although the largest source of pollutants in marinas is upland runoff from storm drains, the kinds of pollutants generated by recreational boaters are diverse and tough to handle. Pollutants include not only the obvious offenders sewage, garbage, trash, oil and fuel - but also heavy metals from antifouling paints, zinc anodes, sanding dust, paint, varnish, cleaners and other materials used in boat maintenance.

Marina managers, government agencies and environmental groups expressed interest in working together in addressing the require- 
recommendations on working with the boating industry have come from as far away as Florida, New York and Guam. Monitoring marinas for pollution control and water quality improvements is beyond the scope of this project and the jurisdiction of the Sea Grant Extension Program. However, it is clear that the project played a vital part in providing educational resources and helping to stimulate awareness and adoption of best management practices for pollution prevention.

With special assistance from the Division of Agriculture and Natural Resources, we are now looking at some economic aspects of boating pollution. We hope to learn what information recreational boaters and the boating industry need to help them choose practices and products that are both economical and effective for reducing pollution.

L.T. Johnson is California Sea Grant's Extension Advisor for San Diego, Orange, and Los Angeles counties.

Dr. Valerie Mellano, UCCE Environmental Issues Advisor, was coleader of the agricultural program. Erika McCoy and Clay Clifton, UCCE Program Representatives, assisted in the recreational boating program.

\section{References}

Johnson LT. 1996. How effective are consensus and education in promoting boating pollution prevention? In Bigford TE, Boyles RH, Jr, editors. Proceedings of the Coastal Society 15 th International Conference; 1996 Jul 14-17 p 292-8.

Johnson LT, Mellano VJ. 1993. How can agriculture reduce its impact on coastal water quality? Building a Consensus for Action. San Diego: UC Cooperative Extension. $10 \mathrm{p}$.

McCoy EJA, Clifton CB, Johnson LT. 1995. Marina pollution prevention manual. UC Sea Grant Extension Program, San Diego. 26 p.

McCoy EJA, Johnson LT. 1995. Boating pollution economics and impacts. San Diego: UC Sea Grant Extension Program. 4 p.

McCoy EJA, Johnson LT. 1995. Clean boating bibliography, annotated. San Diego: UC Sea Grant Extension Program. $30 \mathrm{p}$.

United States Environmental Protection Agency. 1993. Coastal Nonpoint Source Pollution Control Program. Program Development and Approval Guidance. USEPA Office of Water.

United States Environmental Protection Agency. 1993. Guidance Specifying Management Measures for Sources of Nonpoint Pollution in Coastal Waters. USEPA Office of Water.

\section{continued from p. 24}

advisor emeritus John Richards, who in the 1980s successfully mediated between the offshore oil industry and commercial trawl fishers. Johnson has also helped resolve conflict between the local sea urchin fishery and a kelp processor and worked with marinas to reduce pollution from recreational boating (see page 24 ).

\section{Charting the future}

The Sea Grant Extension Program charts its course to reflect broad input from those in marinedependent industries, resource-related agencies and academia. Panels representing both the aquaculture and seafood industries, for instance, advise Sea Grant on their research and extension needs.

The Resources Agency Sea Grant Advisory Panel, consisting of representatives of the numerous state agencies that manage the affairs of California's 1,100-mile coast, also provides recommendations for Sea Grant on research and education needs.

Within the university, the advisors and specialists meet three or four times a year to discuss ideas, plan collaboratively and update each other on their progress. Program priorities are reviewed annually to address national, regional and state priorities. The national goals currently guiding Sea Grant's vision emphasize economic leadership, coastal ecosystem health, public safety, education and human resources. How these goals translate into specific programs in the years ahead is difficult to predict.

Indications as to how these goals translate into specific programs were brought into focus at a recent major conference on California and the "world ocean." The conference - the largest in 30 years - identified a wide variety of high-priority issues affecting ocean and coastal management, including many that Sea Grant Extension Program personnel are currently working on marine protected areas, innovative fisheries management strategies, water quality education, mariculture technical assistance and coastal economic development.

"While the specific challenges may be different, the need for similar processes to resolve them is not," Dewees says. "The challenges of coastal and ocean management can only be achieved through communication, collaboration, community involvement, scientific investigation and effective implementation. The Sea Grant Extension Program will continue to be a critical link in carrying out these processes to address the urgent needs of California's marine environment." - John Stumbos 